Article

\title{
The Growth of Private Sector and Financial Development in Saudi Arabia
}

\author{
Mohammad Imdadul Haque $\mathbb{D}$ \\ College of Business Administration, Prince Sattam Bin Abdulaziz University, Al-Kharj 11942, Saudi Arabia; \\ m.haque@psau.edu.sa
}

Received: 5 April 2020; Accepted: 7 May 2020; Published: 12 May 2020

check for updates

\begin{abstract}
In an attempt to diversify itself away from the dominance of oil on its economy, Saudi Arabia needs to emphasize on the growth of its private sector. Currently, the private sector's contribution to economic growth is meager as the oil sector dominates the economy. This study attempts to assess the role of financial development towards the growth of the private sector. Assessing this relationship is important, as it is quite probable that the dominant oil sector attracts the financial resources, affecting the private sector adversely. Johansen's method of cointegration is applied on the data for the period 1985-2018. The private sector's gross domestic product has a negative relation with the supply of money, positive relation with bank credit to private sector, and no significant relationship with share market capitalization, as shown by the results of the study. In addition, the private sector's growth has a positive and significant relationship with government expenditure, investment, and trade openness. Hence, the study recommends further strengthening of financial sector services. Besides the current trend on government expenditure, investment and trade openness should continue to enable the private sector to contribute significantly to the economic growth of the country. A previous study on the private sector's growth and financial variables is exclusively missing, and makes this study unique.
\end{abstract}

Keywords: broad money; share market; bank credit; private sector growth

JEL Classification: E44; G60; G19; 043

\section{Introduction}

Financial development is important for economic growth as it mobilizes savings and assists in capital accumulation. It is the process of strengthening the quantity and quality of the financial intermediation services. These intermediaries not only mobilize investment funds, but also regulate the efficient allocation of the resources. Besides financing, many things like selecting, screening, risk management, corporate governance, and monitoring business come in the realm of a financial system. In fact, the modern financial environment encompasses a wide range of activities like trading, risk pooling, hedging, and likewise. Basically, an efficient financial system leads to productive investment prospects, which leads to improvements in macroeconomic performance and facilitate economic growth.

The study on the relationship between financial development and economic growth can be traced back to the work of Schumpeter (1911), who established that the financial system acted as a catalyst to promote technological innovation, and ultimately economic growth. In a related study, Robinson (1952) documented a positive relationship between financial development and economic development. Subsequent studies by McKinnon (1973) and Shaw (1973) further strengthened the opinion and led to the development of financial liberalization hypothesis, which called for curtailing state restrictions to promote investment. Even the recent endogenous growth theory proposes that 
financial development and growth are endogenous (Greenwood and Jovanovic 1990) and financial growth positively impacts steady-state growth (King and Levine 1993).

A related debate emerged as to whether financial development was 'demand following' or 'supply leading' (Patrick 1966). Both of them refer phenomenon when growth leads to financial development or economic growth. As argued by Robinson (1952), Lucas (1988), and Stern (1989), an economic growth leads to further demand for financial services, which result in the development of the financial sector. This demand following financial development gave a passive role to financial institutions in promoting economic growth as compared with the active role given by the supply leading phenomenon to the financial development of the financial institutions.

The link between the private sector and financial development has a theoretical underpinning in terms of the first theorem of welfare economics. It reveals that competitive markets are efficient in a Pareto sense as well as in terms of the efficient market hypothesis, which further declares that financial markets use information efficiently. The combination of these two factors leads to the efficient use of the factors of production, leading to economic growth. This financial development is more likely to happen in the private sector, which happens to be a free market for factors of production with minimal government interference and devoid of inefficient market distortions (Eatwell 1996; Jehle and Reny 2001, Aziakpono 2013).

Saudi Arabia is an oil-dominated economy and is currently trying to diversify itself away from excessive dependence on oil (Belloumi and Alshehry 2018). The current research explores the association between financial development and economic diversification in a developing country enriched with oil reserves. Nations with oil resources, dominating the gross domestic product (GDP), have distinct features compared with industrialized nations, and those resources are highly regulated by the state. That implies that, in such countries, the financial resources are diverted to its predominant oil sector. Saudi Arabian Monetary Agency (SAMA), the central bank of the country, provides estimations for GDP by institutional sector. It divides the data for GDP into 'oil sector', non-oil private sector', and 'non-oil government sector. Though the oil sector is controlled by the state, the database tries to differentiate between the oil sector and the non-oil government sector. Between 1985 and 2018, the contribution of the oil sector to GDP decreased from $46.02 \%$ to $43.84 \%$, the contribution of the non-oil government sector decreased from $21.72 \%$ to $19.96 \%$, while the contribution of the non-oil private sector increased from $32.25 \%$ to $39.54 \%$ (SAMA 2019).

Few important timelines are to be considered while studying the growth of the private sector in Saudi Arabia. In 2002, twenty new fields were set up in the private sector for the first time, which were previously under the government sector. In 2005, Saudi Arabia joined World Trade Organization, which led to the beginning of privatization in the kingdom. One of the strategic objectives of the National Transformation Plan was to restructure for the growth of the private sector, and it achieved this in 2016. The emphasis is on the private sector to contribute more in high potential less-developed regions like railway projects, health, water, housing, education, and so on. Further, the kingdom has brought in some major transformations to its economic policies in order to achieve its Vision 2030. In the process, it has extended a lion's share to the development of the private sector. The target as per Vision 2030 is to achieve a non-oil private sector contribution of $65 \%$ of GDP (Vision 2030). Therefore, in light of these discussions, the current research attempts to explore the influence of financial variables on the non-oil private sector growth of Saudi Arabia.

The private sector reduces the burden of the public sector and improves efficiency as it works on the principles of competitiveness. A private sector entity ceases to exist simply when it is no longer profitable. This is in contrast to the public sector, which must function even if is straightaway not leading to profits, like defense, subsidies, and social development. For the functioning of the private sector, apart from regular macroeconomic variables like investment, government expenditure, and trade openness, financial variables are also crucial. These financial variables indicate availability of funds to the private sector. Fund allocation in the private sector is purely based on merit. This merit is based on competitiveness and profitability. Money supply, bank credit to the private sector, and 
share market capitalization are some of the important financial variables impacting the functioning of an economy. A flourishing private sector is essential for any vibrant economy.

The study aims to test the hypothesis that financial development leads to the growth of the private sector in Saudi Arabia. The study plans to study the long-run relationship between the variables towards which the study would first test the data for stationarity. The stationarity characteristics of the data would decide upon the method to be adopted by the study. If the data are stationary at level, the ordinary least squares (OLS) method would suffice the purpose. If the variables are stationary at first difference, which happens to be the most probable case for time series, the method of cointegration can be employed to study the relationship. If there is cointegration between the variables, the short-run relationship can be established through the vector error correction model (VECM). Moreover, in the case of absence of cointegration, the study would proceed with Granger causality in the vector autoregresssive (VAR) framework. The remaining part of the paper is as follows: the next section discusses the previous research studies, followed by data, methodology, empirical analysis, and discussion. The paper finally ends with insights upon which to throw light.

\section{Review of the Literature}

Financial development promotes economic growth as it stimulates domestic investment, augmenting savings in the economy, which reduces the cost of capital. It also promotes economic growth indirectly through development of institutions and improved governance, and instills macroeconomic prudence (Henry 2006; Kose et al. 2006). It is a customary saying in financial economics that a well-developed financial system proliferates economic performance. The erstwhile research suggests that financial growth effectively ventures to reward investment scenarios, enhance corporate control, mitigate different types of costs, increase expert knowledge, and so on (Darrat et al. 2005).

Empirically, there are many views associated with financial growth and economic development. Firstly, some researchers opine that financial growth influences economic development (De Gregorio and Kim 2000; Christopoulos and Tsionas 2004; Hamdi 2015). Secondly some opine that economic development leads to financial growth (Rajan and Zingales 1998; Al-Yousif 2002; Al-Malkawi et al. 2012; Grassa and Gazdar 2014). Thirdly, few researchers say that there is a two-way association between financial growth and economic development (Greenwood and Smith 1997; Abu-Bader and Abu-Qarn 2008). Finally, some researchers feel neither economic development nor financial growth influences each other (Stern 1989; Loayza and Ranciere 2006). Financial development has an added dimension for oil-rich economies like Saudi Arabia. It can counterbalance the problem of resource curse by directing oil revenues to productive avenues (Law and Moradbeigi 2017).

The demand for funds to finance production and facilitate capital accumulation specially in the private sector and the subsequent development of the financial sector is acknowledged by Lohmann (1992) and Greenwood and Smith (1997). Moreover, the development of the financial sector, particularly banks and stock markets, assists in corporate financing (Demirgüç-Kunt and Maksimovic 1996). The financial sector helps in mobilizing funds from the surplus sector to prospective companies (Allen and Gale 2004; Greenwood et al. 2013). It also aids the private sector in efficient resource allocation by shifting resources to productive units (Law and Singh 2014; Rioja and Valev 2004). The private sector gets the benefit of financial development as it helps not only in the mobilization of savings and arranging for transactions, but also to get funds for research, corporate control, and risk management (Levine 2005).

The study concentrates on the past literature of the current study in Saudi Arabia. Studies reported a positive effect of financial development on economic growth. Financial growth and economic development have a two-way causality between them (Al-Yousif 2002). Financial growth positively effects economic development through the establishment of a constructive financial system in an economy. The economic variables, such as private bank credit and industrial production, positively affect economic development, while the stock market does not have any impact on it (Ibrahim 2013). A study by Samargandi et al. (2014) reports that there is a positive impact of financial growth on 
the development of non-oil sector, while the opposite is true with the oil sector. Similarly, studies of Marashdeh and Al-Malkawi (2014) and Hathroubi (2019) in the Saudi Arabian context reported a positive effect between financial inclusion and economic development in the long-run using different models, and both the studies found no short-run association between the two variables.

Apart from the above named studies, some other studies concentrated on the countries in the Gulf Cooperation Council (GCC) and Organization of Islamic countries (OIC). Darrat (1999), and Hassan et al. (2011) found a positive association between financial depth and economic development in the long-run using the error correction model (ECM) framework in Middle Eastern countries. Similarly, there were comparative effects of Islamic financial growth and traditional financial growth on the economic development of GCC nations, and Grassa and Gazdar (2014) predicted Islamic financial growth leading to economic development rather than traditional financial growth. While studying the OIC countries, Duasa (2014) reported a causal association between financial growth and economic development with regard to Saudi Arabia. Furthermore, Hamdi et al. (2014) found a significant positive relationship between financial growth and economic development in the GCC nations, and the positive impact of financial growth on economic development is related to foreign direct investment, fixed capital formation, and production of oil (Muhammad et al. 2016).

Other studies reported a negative effect of financial development on economic growth. For Saudi Arabia, Mahran (2012) found a negative impact of financial deepening on the growth rate. The study noted that the public sector influence in the country is large and it leaves very small space for the private sector. The study also reported low quality and carelessness in granting bank credit. Similarly, the study of Al-Tamimi et al. (2001) found a weak causal relationship between financial growth and economic development, and no bi-directional effect in some cases. Few other studies of multiple countries that examined the financial growth and economic development reported a negative association between the two owing to the influence of some factors, such as inflation, exports, and so on (Gillman and Harris 2004; Samargandi et al. 2014).

Few other studies reported no effect of financial development on economic growth. The influence of financial growth on economic development is in primeval stage and different economic sector reforms need to be undertaken (Masih et al. 2009). A similar study by Rehman (2018) on Saudi Arabia found no long-run relationship between financial growth and economic development and suggested to introduce efficient financial sector reforms in the kingdom. Further, different macro-economic variables have different impacts on financial growth in different regions of the world, and sometimes have an insignificant impact (Ayad and Belmokaddem 2017; Kouki 2013).

In summary, the study examines the research works of (Darrat 1999; Hassan et al. 2011; Ibrahim 2013; Grassa and Gazdar 2014; Hamdi et al. 2014; Marashdeh and Al-Malkawi 2014; Muhammad et al. 2016), which report a positive association between financial growth and economic development. In contrast, the studies of Rehman (2018) and Ayad and Belmokaddem (2017) reported no significant association between financial growth and economic development. Meanwhile, Al Tamimi (2001), Gillman and Harris (2004), Mahran (2012), Masih et al. (2009), Barajas et al. (2013), Samargandi et al. (2014), Kouki (2013), and Law and Moradbeigi (2017) reported negative and low-quality relationships between the two variables.

It is evident from the above-referred studies that there are empirical researchers studying the relationship between financial variables and economic growth. However, there is a literature gap in terms of studies that analyze the relationship between only private sector growth and financial variables. This is also more significant for a country that is planning to diversify itself and facilitate the growth of its private sector.

\section{Model and Methodology}

One of the frequently used indicators of financial development is broad money, measured by M2. It signifies the degree of financial intermediation and denotes the volume of the financial sector (King and Levine 1993). It increases with the growth of the financial sector. The other alternatives are M1 
and M3. The variable M2 as a proportion of GDP has been used as a proxy for financial development by Darrat et al. (2006), Masih et al. (2009), Samargandi et al. (2014), Hamdi et al. (2014), Duasa (2014), Law and Moradbeigi (2017), and Rehman (2018). The variable bank credit as a proportion of GDP is considered an effective and dependable measure of financial depth (Beck 2011). A developed financial system allocates additional credit to the private sector. The variable bank credit as a proportion of GDP has been used as a proxy for financial development by Darrat et al. (2006), Masih et al. (2009), Hassan et al. (2011), Mahran (2012), Ibrahim (2013), Kouki (2013), Grassa and Gazdar (2014), Samargandi et al. (2014), Marashdeh and Al-Malkawi (2014), Hamdi et al. (2014), Duasa (2014), and Law and Moradbeigi (2017). The next variable stock market is also positively and strongly related with economic growth in the long run (Levine and Zervos 1998). The variable share market value of shares as proportion of GDP has been used as a proxy for financial development by Kouki (2013), Ibrahim (2013), Samargandi et al. (2014), and Rehman (2018). The raw data are summarized in Table 1 given below.

Table 1. Descriptive statistics of the raw data (million riyals).

\begin{tabular}{ccccccccc}
\hline Variables & PRGDP & M2 & BC & S & I & T & G & GDP \\
\hline Mean & 498,419 & 590,267 & 477,375 & 788,615 & 279,792 & 938,927 & 297,403 & $1,235,838$ \\
Standard Error & 66,440 & 93,342 & 83,120 & 126,462 & 40,252 & 128,085 & 36,287 & 157,885 \\
Median & 285,021 & 290,724 & 196,447 & 278,000 & 127,081 & 471,858 & 186,606 & 710,852 \\
Standard Deviation & 387,406 & 544,273 & 484,667 & 737,395 & 234,710 & 746,856 & 211,588 & 920,618 \\
Kurtosis & -0.48363 & -0.53987 & -0.57122 & -1.14874 & -1.0649 & -1.15742 & -0.34489 & -1.10359 \\
Skewness & 1.021382 & 1.000469 & 0.960771 & 0.58902 & 0.79311 & 0.679613 & 1.049594 & 0.73251 \\
Range & $1,140,369$ & $1,541,099$ & $1,389,115$ & $2,374,600$ & 669,876 & $2,114,565$ & 636,916 & $2,628,526$ \\
Minimum & 160,486 & 122,721 & 56,137 & 63,400 & 62,556 & 201,228 & 102,240 & 320,931 \\
Maximum & $1,300,856$ & $1,663,820$ & $1,445,252$ & $2,438,000$ & 732,432 & $2,315,793$ & 739,156 & $2,949,457$ \\
\hline
\end{tabular}

Note: PRGDP is the private sector GDP; M2 is currency outside banks + demand deposits + time and saving deposits; $\mathrm{BC}$ is bank claims on the private sector; $\mathrm{S}$ is market value of shares; I is gross domestic capital formation; $\mathrm{T}$ stands for exports + imports; G stands for government final consumption expenditure; GDP stands for gross domestic product.

The study also controls the macroeconomic indicators, namely, government expenditure, investment, and trade openness in the country. The variable government expenditure as a proportion of GDP has been used in studies on financial development and economic growth by Hassan et al. (2011), Samargandi et al. (2014), Marashdeh and Al-Malkawi (2014), and Law and Moradbeigi (2017). The variable investment as a proportion of GDP has been used in studies on financial development and economic growth by Mahran (2012), Hamdi et al. (2014), and Duasa (2014). The variable trade openness (export plus import divided by GDP) has been used in studies on financial development and economic growth by Hassan et al. (2011), Mahran (2012), Grassa and Gazdar (2014), Samargandi et al. (2014), and Marashdeh and Al-Malkawi (2014). Lastly, to study the impact of these financial development variables and control variables on the private sector, the study used private sector GDP as a proportion of total GDP as the dependent variable.

The basic model used by this study is

$$
\operatorname{lnrPRGDP} t=\alpha_{0}+\beta_{1} \ln \ln _{t}+\beta_{2} \ln \operatorname{lnC}_{t}+\beta_{3} \operatorname{lnr} S_{t}+\beta_{4} \operatorname{lnrG} t+\beta_{5} \operatorname{lnr} I_{t}+\beta_{6} \ln \operatorname{TO}_{t}+\varepsilon_{t}
$$

where $\mathrm{rPRGDP}=\frac{\mathrm{PRGDP}}{\mathrm{GDP}}$ is the ratio of private sector gross domestic product to GDP; $\mathrm{rM} 2=\frac{\mathrm{M} 2}{\mathrm{GDP}}$ is the ratio of broad money to GDP; $\mathrm{rBC}=\frac{\mathrm{BC}}{\mathrm{GDP}}$ is the ratio of bank credit to private sector to GDP; $\mathrm{rS}=\frac{\mathrm{S}}{\mathrm{GDP}}$ is the ratio of market value of shares to GDP; $r G=\frac{G}{G D P}$ is the ratio of government expenditure to GDP; $\mathrm{rI}=\frac{\mathrm{I}}{\mathrm{GDP}}$ is the ratio of gross domestic capital formation to GDP; and $\mathrm{rTO}=\frac{\mathrm{TO}}{\mathrm{GDP}}$ is the ratio of exports and imports to GDP. The research aims to study the relationship of financial sector variables on the gross domestic product of the private sector. The financial sector variables taken here are broad money, bank credit to the private sector, and share market capitalization. The other three variables incorporated in the model, namely, government expenditure, investment, and trade, are control variables in the study. This study uses the data from Saudi Arabian Monetary Agency (SAMA), from 1985 to 2018, and 
in million dollars at current prices. While testing for a relationship, the basic model takes the log of the variables. It is indicated by ' $1 n$ ' prefixed to the variable name. EViews 10 is used to analyze the data.

First, the data are tested for stationarity as the data are time series in nature. To test for stationarity in the variables, this study proposes to use the augmented Dickey Fuller (ADF) test. The ADF test is basically in the autoregressive (AR) process. In the AR (1) process, the equation is estimated as follows

$$
\Delta Y_{t}=\alpha+\delta Y_{t-1}+\varepsilon_{t}
$$

The null and alternate hypotheses are as follows:

$$
\mathrm{H}_{0}: \delta=0 \text { and } \mathrm{H}_{\mathrm{a}}: \delta<0
$$

In $\mathrm{AR}(2)$ process, the equation is as follows:

$$
\Delta Y_{t}=\alpha+\delta Y_{t-1}+\beta \Delta Y_{t-1}+\varepsilon_{t}
$$

The null and alternate hypotheses are as follows:

$$
\mathrm{H}_{0}: \delta=0 \text { and } \mathrm{H}_{\mathrm{a}}: \delta<0
$$

The study also uses the Phillips Perron (PP) test for stationarity. The equation given below estimates the PP test:

$$
Y_{t}=\alpha+\rho Y_{t-1}+\varepsilon_{t}
$$

where $\alpha$ is the constant, $\rho Y_{t-1}$ is the non-parametric correction to the t-test for serial correlation, and $\varepsilon_{t}$ is error term. The null and alternate hypotheses are as follows:

$$
\mathrm{H}_{0}: \rho=1 \text { and } \mathrm{H}_{\mathrm{a}}: \rho<1
$$

To test for cointegration, this study proposes to use Johansen (1995) cointegration test. The null and alternate hypothesis are as follows:

$$
\mathrm{H}_{0}: \mathrm{r}=0 \text { and } \mathrm{H}_{\mathrm{a}}: \mathrm{r} \geq 1
$$

where $r$ is the rank of cointegration. If the null hypothesis is accepted, it indicates no cointegrating relationships between the variables. Once the results reject the null hypothesis, another set of hypotheses is tested.

$$
\mathrm{H}_{0}: \mathrm{r} \leq 0 \text { and } \mathrm{H}_{\mathrm{a}}: \mathrm{r} \geq 2
$$

Until the acceptance of the null hypothesis, the process repeats. Finally, the smallest value of $r$ decides the number of cointegrating vectors. Trace statistics and Max-Eigen statistics lead to the decision.

After ascertaining the cointegrating relationship between the variables, the vector error correction model (VECM) estimates the equilibrating relationship between the variables. The equation given below is estimated.

$$
\begin{aligned}
\Delta \operatorname{lnrPRGDP}_{t}=\alpha_{0}+\varphi_{1} \mathrm{ECT}_{t-1} & +\sum_{i=1}^{k} \beta_{1 i} \Delta \operatorname{lnrM} 2_{t-i}+\sum_{i=1}^{k} \beta_{2 i} \Delta \operatorname{lnnBC}_{t-i}+\sum_{i=1}^{k} \beta_{1 i} \Delta \operatorname{lnnS}_{t-i}+\sum_{i=1}^{k} \beta_{2 i} \Delta \operatorname{lnrG}_{t-i} \\
& +\sum_{i=1}^{k} \beta_{1 i} \Delta \operatorname{lnrI}_{t-i}+\sum_{i=1}^{k} \beta_{2 i} \Delta \operatorname{lnrTO}_{t-i}+\varepsilon_{1 t}
\end{aligned}
$$

Further, residual diagnostics is proposed. The Breusch-Godfrey serial correlation test is used to test for serial correlation; Breusch-Pagan-Godfrey is used to test for heteroscadisticity; and Jarque-Bera is used to check for normality. Finally, Wald's test is used to test for short-run relationships. 


\section{Results and Discussion}

The results of stationary testing of the variables are presented in Table 2 . Here, the null hypothesis is that the data series is stationary and the alternate hypothesis is that the data are stationary. The results indicate that all the variables have unit roots and become stationary at first difference, except for one variable. The variable bank credit $(\mathrm{rBC})$ is stationary at level when the ADF test is calculated at constant with a linear trend. However, at constant and none criteria, $\mathrm{rBC}$ is not stationary at level. Hence, the study proposes to check for stationarity using an alternative Phillips Perron (PP) test.

Using the Phillips Perron test, the study finds that all the variables are non-stationary at level (Table 2). In addition, all the variables are stationary at first difference. Bank credit that was non-stationary at level in the ADF test is stationary at level according to the PP test. Hence, the ordinary least squares (OLS) method of regression is unable to estimate the relationship. Further testing shows that the data are stationary at first difference. The ADF and PP tests have been jointly used by studies that have reported that PP tests are sharper than ADF tests, as they adjust for possible serial correlation (Hasanov et al. 2016; Huang 2019).

As the data are stationary at first difference, the study applies Johansen's method of cointegration to test the relationship between the variables. Towards this, the study first estimates the lag order in the vector autoregressive (VAR) framework. The results suggest taking lag one based on SC criteria (Table 3). Upon performing Johansen's method of cointegration, the results indicate the presence of a cointegrating relationship between the variables. In fact, both trace statistics and Max-Eigen statistics indicate the presence of four cointegrating vectors (Table 4). This simply indicates the presence of four different linear combinations of the variables under study (Wickens 1996). Estimating more than one cointegrating equation has little statistical inference if not supported by theoretical foundation (Agoraki et al. 2019). In fact, the researcher needs to consider the economic theory and choose the equation with practical explanation (Dibooglu 1993).

The long-run equation is estimated as Equation (11) given below:

$$
\operatorname{lnrPRGDP}{ }_{t}=0.21-1.97 \operatorname{lnrM} 2_{t}^{* *}+0.88 \operatorname{lnrBC} C_{t}^{* *}+0.03 \operatorname{lnr} S_{t}+1.43 \operatorname{lnr} G_{t}^{* *}+0.75 \operatorname{lnr} t_{t}^{* *}+0.22 \operatorname{lnr} T_{t}^{* *}+\varepsilon_{t}
$$

As the presence of cointegration is confirmed, the study moves to estimate the VECM (Table 5). The results show that the error correction term is -0.66591 and is significant (Table 6). This satisfies both conditions for the error correction term (ECT), which is to be negative and less than one. This indicates that any disequilibrium corrects itself by $66.59 \%$ in one time-period. The presence of cointegration between the financial variables has been reported by all of the previous studies except for Rehman (2018), which reported no cointegration between real GDP, M2/GGP, and the stock market. A probable reason could be non-inclusion for control variables in the said study.

Further, the study performs residual diagnostics (Table 7). The Breusch-Godfrey Serial Correlation Lagrange Multiplier (LM) test results support the null hypothesis that there is no serial correlation in the model. The Breusch-Pagan-Godfrey test supports the null hypothesis that the residuals are homoscedastic. In addition, the Jarque-Bera test supports the null hypothesis that the residuals are normally distributed. These robustness checks indicate that the studied model is fit. Finally, the study analyzes the short-run relationships. The study finds no relationship between the explanatory variables and private sector GDP in the short run at a 5\% level of significance (Table 8). Only broad money and investment are significant at a $10 \%$ level of significance. 
Table 2. Augmented Dickey Fuller (ADF) test results.

\begin{tabular}{|c|c|c|c|c|c|c|c|c|c|c|c|c|c|c|}
\hline \multirow{2}{*}{ Variables } & \multicolumn{2}{|c|}{ rPRGDP } & \multicolumn{2}{|c|}{ rM2 } & \multicolumn{2}{|c|}{$\mathrm{rBC}$} & \multicolumn{2}{|c|}{ rS } & \multicolumn{2}{|c|}{$\mathrm{rG}$} & \multicolumn{2}{|c|}{ rI } & \multicolumn{2}{|c|}{ rTO } \\
\hline & t-stat & Prob & t-stat & Prob & t-stat & Prob & t-stat & t-stat & t-stat & Prob & t-stat & Prob & t-stat & Prob \\
\hline Constant & -2.00 & 0.28 & -1.01 & 0.74 & -2.23 & 0.2 & -1.18 & -2.23 & -2.23 & 0.2 & -1.18 & 0.67 & -1.62 & 0.46 \\
\hline Const, Linear Trend & -1.98 & 0.59 & -2.47 & 0.34 & -2.08 & 0.54 & -2.42 & -2.08 & -2.08 & 0.54 & -2.42 & 0.36 & -1.55 & 0.79 \\
\hline None & -0.05 & 0.66 & 1.25 & 0.94 & -0.15 & 0.62 & 0.3 & -0.15 & -0.15 & 0.62 & 0.3 & 0.77 & 0.11 & 0.71 \\
\hline Variables & \multicolumn{2}{|c|}{ rPRGDP(-1) } & \multicolumn{2}{|c|}{ rM2(-1) } & \multicolumn{2}{|c|}{$\mathrm{rBC}(-1)$} & \multicolumn{2}{|c|}{$\mathrm{rS}(-1)$} & \multicolumn{2}{|c|}{$\mathrm{rG}(-1)$} & \multicolumn{2}{|c|}{ rI(-1) } & \multicolumn{2}{|c|}{ rTO(-1) } \\
\hline Constant & -5.29 & 0 & -4.80 & 0 & -6.63 & 0 & -5.43 & -6.63 & -6.63 & 0 & -5.43 & 0 & -4.87 & 0 \\
\hline Const, Linear Trend & -5.49 & 0 & -5.74 & 0 & -6.73 & 0 & -5.32 & -6.73 & -6.73 & 0 & -5.32 & 0 & -4.90 & 0 \\
\hline None & -5.38 & 0 & -5.64 & 0 & -6.72 & 0 & -5.50 & -6.72 & -6.72 & 0 & -5.50 & 0 & -4.94 & 0 \\
\hline \multicolumn{15}{|c|}{ Phillips Perron test results. } \\
\hline \multirow{2}{*}{ Variables } & \multicolumn{2}{|c|}{ rPRGDP } & \multicolumn{2}{|c|}{ rM2 } & \multicolumn{2}{|c|}{ rBC } & \multicolumn{2}{|c|}{ rS } & \multicolumn{2}{|c|}{ rG } & \multicolumn{2}{|c|}{ rI } & \multicolumn{2}{|c|}{ rTO } \\
\hline & t-stat & Prob & t-stat & Prob & t-stat & Prob & t-stat & Prob & t-stat & Prob & t-stat & Prob & t-stat & Prob \\
\hline Constant & -2.00 & 0.28 & -0.99 & 0.74 & -0.85 & 0.79 & 2.05 & 0.27 & -2.18 & 0.21 & -1.19 & 0.67 & -1.62 & 0.46 \\
\hline Const, Linear Trend & -1.92 & 0.62 & -2.51 & 0.32 & -2.57 & 0.29 & -2.47 & 0.34 & -2.08 & 0.53 & -2.43 & 0.36 & -1.55 & 0.79 \\
\hline None & -0.05 & 0.66 & 2.19 & 0.99 & 6.49 & 1 & 1.36 & 0.95 & -0.18 & 0.61 & 0.33 & 0.78 & 0.11 & 0.71 \\
\hline Variables & \multicolumn{2}{|c|}{ rPRGDP(-1) } & \multicolumn{2}{|c|}{ rM2(-1) } & \multicolumn{2}{|c|}{$\mathrm{rBC}(-1)$} & \multicolumn{2}{|c|}{$\mathrm{rS}(-1)$} & \multicolumn{2}{|c|}{ rG(-1) } & \multicolumn{2}{|c|}{$\mathrm{rI}(-1)$} & \multicolumn{2}{|c|}{ rTO(-1) } \\
\hline Constant & -5.27 & 0 & -6.01 & 0 & -7.99 & 0 & -7.66 & 0 & -6.80 & 0 & -5.40 & 0 & -4.84 & 0 \\
\hline Const, Linear Trend & -7.36 & 0 & -8.31 & 0 & -7.72 & 0 & -7.72 & 0 & -10.61 & 0 & -5.29 & 0 & -4.86 & 0 \\
\hline None & -5.37 & 0 & -5.76 & 0 & -4.43 & 0 & -7.46 & 0 & -6.87 & 0 & -5.50 & 0 & -4.92 & 0 \\
\hline
\end{tabular}


Table 3. Lag structure.

\begin{tabular}{ccccccc}
\hline Lag & LogL & LR & FPE & AIC & SC & HQ \\
\hline $\mathbf{0}$ & 753.44 & NA & $1.29 \mathrm{e}-29$ & -46.65 & -46.33 & -46.55 \\
$\mathbf{1}$ & 905.99 & 228.81 & $2.16 \mathrm{e}-32$ & -53.12 & $-50.55^{*}$ & -52.27 \\
$\mathbf{2}$ & 978.87 & $77.43^{*}$ & $7.84 \mathrm{e}-33^{*}$ & $-54.61^{*}$ & -49.81 & $-53.02 *$ \\
\hline
\end{tabular}

* Denotes the selected lag length for the given criteria. LR: sequential modified LR test statistic; FPE: Final prediction error; AIC: Akaike information criterion; HQ: Hannan-Quinn information criterion; SC: Schwarz information criterion.

Table 4. Cointegrating relationships.

\begin{tabular}{|c|c|c|c|c|c|c|c|c|}
\hline \multirow[b]{2}{*}{ No. of CE(s) } & \multicolumn{4}{|c|}{ Trace } & \multicolumn{4}{|c|}{ Max-Eigen } \\
\hline & Eigen Value & Statistic & Critical Value & Prob. ** & Eigen Value & Statistic & Critical Value & Prob. ** \\
\hline None * & 0.97 & 272.22 & 111.78 & 0.00 & 0.97 & 114.45 & 42.77 & 0.00 \\
\hline At most $1 *$ & 0.88 & 157.76 & 83.93 & 0.00 & 0.88 & 66.56 & 36.63 & 0.00 \\
\hline At most $2 *$ & 0.75 & 91.19 & 60.06 & 0.00 & 0.752 & 43.33 & 30.43 & 0.00 \\
\hline At most 3 * & 0.48 & 47.86 & 40.17 & 0.00 & 0.48 & 20.52 & 24.15 & 0.14 \\
\hline At most $4 *$ & 0.42 & 27.34 & 24.27 & 0.01 & 0.42 & 17.26 & 17.79 & 0.05 \\
\hline At most 5 & 0.22 & 10.07 & 12.32 & 0.11 & 0.22 & 7.78 & 11.22 & 0.18 \\
\hline At most 6 & 0.07 & 2.28 & 4.12 & 0.15 & 0.07 & 2.28 & 4.12 & 0.15 \\
\hline
\end{tabular}

${ }^{*}$ Denotes rejection at 0.05 level. ${ }^{* *}$ MacKinnon-Haug-Michellis $p$-values.

Table 5. Vector error correction model.

\begin{tabular}{|c|c|c|c|c|c|c|c|}
\hline Cointegrating Eq: & CointEq1 & Variables & Variables & Variables & Variables & Variables & Variables \\
\hline $\ln r$ PRGDP(-1) & 1.000000 & & & & & & \\
\hline \multirow[t]{3}{*}{$\operatorname{lnrM} 2(-1)$} & 1.973332 & & & & & & \\
\hline & $(0.25029)$ & & & & & & \\
\hline & [7.88408] & & & & & & \\
\hline \multirow{3}{*}{$\ln \mathrm{BC}(-1)$} & -0.8888 & & & & & & \\
\hline & $(0.14114)$ & & & & & & \\
\hline & {$[-6.29711]$} & & & & & & \\
\hline \multirow{3}{*}{$\ln r S(-1)$} & -0.03002 & & & & & & \\
\hline & $(0.03079)$ & & & & & & \\
\hline & {$[-0.97509]$} & & & & & & \\
\hline \multirow[t]{3}{*}{$\ln r G(-1)$} & -1.43403 & & & & & & \\
\hline & (0.11298) & & & & & & \\
\hline & {$[-12.6925]$} & & & & & & \\
\hline \multirow[t]{3}{*}{$\ln r(-1)$} & -0.75161 & & & & & & \\
\hline & $(0.07841)$ & & & & & & \\
\hline & [-9.58608] & & & & & & \\
\hline \multirow[t]{3}{*}{$\ln \mathrm{TO}(-1)$} & 0.229554 & & & & & & \\
\hline & $(0.06496)$ & & & & & & \\
\hline & [3.53394] & & & & & & \\
\hline C & -0.2117 & & & & & & \\
\hline Error Correction: & D(lnrPRGDP) & $\mathrm{D}(\ln r \mathrm{M} 2)$ & $\mathrm{D}(\ln \mathrm{BC})$ & $\mathrm{D}(\ln r S)$ & $\mathrm{D}(\ln r \mathrm{G})$ & D(Ilnr) & $\mathrm{D}(\ln \mathrm{TO})$ \\
\hline \multirow[t]{3}{*}{ CointEq1 } & -0.66591 & -0.60445 & -0.81684 & 1.963360 & 0.305705 & -0.32957 & 0.418680 \\
\hline & $(0.25394)$ & $(0.24620)$ & $(0.39175)$ & $(0.83594)$ & $(0.37387)$ & $(0.29126)$ & $(0.23059)$ \\
\hline & {$[-2.62231]$} & {$[-2.45506]$} & {$[-2.08510]$} & [2.34867] & [0.81767] & {$[-1.13150]$} & [1.81569] \\
\hline \multirow[t]{3}{*}{ D(lnrPRGDP(-1)) } & -0.5273 & -1.02349 & -0.84463 & -1.88538 & 0.154440 & -0.79598 & -0.71298 \\
\hline & $(0.63298)$ & $(0.61369)$ & $(0.97649)$ & $(2.08370)$ & $(0.93193)$ & $(0.72601)$ & (0.57477) \\
\hline & {$[-0.83304]$} & {$[-1.66775]$} & {$[-0.86496]$} & {$[-0.90482]$} & [0.16572] & {$[-1.09638]$} & {$[-1.24046]$} \\
\hline \multirow[t]{3}{*}{$\mathrm{D}(\ln r \mathrm{PRGDP}(-2))$} & -0.73404 & -0.31539 & -1.25131 & -3.46561 & 0.867661 & 0.011951 & 0.512124 \\
\hline & $(0.63751)$ & $(0.61809)$ & $(0.98349)$ & (2.09863) & $(0.93860)$ & $(0.73121)$ & $(0.57889)$ \\
\hline & {$[-1.15141]$} & {$[-0.51026]$} & {$[-1.27232]$} & {$[-1.65137]$} & [0.92442] & [0.01634] & [0.88466] \\
\hline \multirow[t]{3}{*}{$\mathrm{D}(\ln r \mathrm{M} 2(-1))$} & 1.174578 & 1.179425 & 2.380032 & 2.465550 & -1.06849 & 1.399585 & -0.09349 \\
\hline & $(0.81661)$ & (0.79173) & (1.25977) & $(2.68819)$ & (1.20228) & $(0.93663)$ & $(0.74152)$ \\
\hline & [1.43836] & [1.48968] & [1.88926] & [0.91718] & {$[-0.88872]$} & [1.49428] & {$[-0.12608]$} \\
\hline \multirow[t]{3}{*}{$\mathrm{D}(\ln r \mathrm{M} 2(-2))$} & 1.401951 & 0.960564 & 1.790914 & 0.982619 & -0.74252 & 0.135906 & -1.30955 \\
\hline & $(0.58267)$ & $(0.56492)$ & $(0.89888)$ & (1.91810) & $(0.85786)$ & $(0.66831)$ & $(0.52909)$ \\
\hline & [2.40607] & [1.70035] & [1.99238] & [0.51229] & {$[-0.86555]$} & [0.20336] & {$[-2.47508]$} \\
\hline \multirow[t]{3}{*}{$\mathrm{D}(\ln \mathrm{BC}(-1))$} & -0.4227 & -0.25864 & -0.81381 & -1.03436 & 0.296840 & -0.5644 & 0.328174 \\
\hline & $(0.38797)$ & $(0.37615)$ & $(0.59852)$ & (1.27717) & (0.57121) & $(0.44500)$ & $(0.35230)$ \\
\hline & [-1.08949] & {$[-0.68759]$} & {$[-1.35969]$} & {$[-0.80988]$} & [0.51967] & {$[-1.26833]$} & [0.93152] \\
\hline
\end{tabular}


Table 5. Cont.

\begin{tabular}{|c|c|c|c|c|c|c|c|}
\hline Cointegrating Eq: & CointEq1 & Variables & Variables & Variables & Variables & Variables & Variables \\
\hline \multirow[t]{3}{*}{$\mathrm{D}(\ln \mathrm{BC}(-2))$} & -0.31256 & -0.16754 & -0.65372 & -0.15852 & 0.047264 & 0.068744 & 0.500384 \\
\hline & $(0.21654)$ & $(0.20994)$ & $(0.33406)$ & $(0.71283)$ & $(0.31881)$ & $(0.24837)$ & $(0.19663)$ \\
\hline & {$[-1.44342]$} & {$[-0.79802]$} & {$[-1.95691]$} & {$[-0.22238]$} & [0.14825] & {$[0.27678]$} & [2.54480] \\
\hline \multirow[t]{3}{*}{$\mathrm{D}(\ln r S(-1))$} & -0.03231 & -0.07665 & 0.092024 & -0.26051 & -0.13687 & 0.048098 & 0.044973 \\
\hline & $(0.06583)$ & $(0.06382)$ & $(0.10155)$ & $(0.21670)$ & $(0.09692)$ & $(0.07550)$ & $(0.05977)$ \\
\hline & {$[-0.49076]$} & {$[-1.20102]$} & [0.90618] & {$[-1.20218]$} & {$[-1.41222]$} & [0.63703] & {$[0.75237]$} \\
\hline \multirow[t]{3}{*}{$\mathrm{D}(\ln \mathrm{S} S(-2))$} & 0.076143 & 0.038365 & 0.229143 & 0.694037 & -0.11738 & 0.140853 & -0.04974 \\
\hline & $(0.08391)$ & $(0.08136)$ & $(0.12945)$ & $(0.27623)$ & $(0.12355)$ & $(0.09625)$ & $(0.07620)$ \\
\hline & {$[0.90740]$} & {$[0.47156]$} & [1.77010] & [2.51249] & {$[-0.95008]$} & [1.46345] & {$[-0.65279]$} \\
\hline \multirow[t]{3}{*}{$\mathrm{D}(\ln r G(-1))$} & -0.19687 & -0.08828 & -0.84665 & 0.627936 & 0.428893 & -0.03263 & 0.121606 \\
\hline & $(0.31381)$ & $(0.30425)$ & $(0.48411)$ & $(1.03302)$ & $(0.46201)$ & $(0.35993)$ & $(0.28495)$ \\
\hline & {$[-0.62735]$} & {$[-0.29015]$} & {$[-1.74888]$} & [0.60786] & [0.92831] & {$[-0.09065]$} & {$[0.42676]$} \\
\hline \multirow[t]{3}{*}{$\mathrm{D}(\ln r \mathrm{G}(-2))$} & -0.29801 & -0.11536 & -0.34995 & -0.50464 & 0.276492 & -0.11987 & 0.241988 \\
\hline & $(0.27446)$ & $(0.26609)$ & $(0.42340)$ & $(0.90348)$ & $(0.40408)$ & $(0.31479)$ & $(0.24922)$ \\
\hline & {$[-1.08583]$} & {$[-0.43351]$} & {$[-0.82653]$} & {$[-0.55855]$} & [0.68425] & {$[-0.38079]$} & [0.97098] \\
\hline \multirow[t]{3}{*}{$\mathrm{D}(\ln \mathrm{I}(-1))$} & -0.68843 & -0.47237 & -0.72176 & 2.132162 & -0.03004 & -0.39438 & 0.425927 \\
\hline & $(0.30533)$ & $(0.29603)$ & $(0.47103)$ & $(1.00511)$ & $(0.44953)$ & $(0.35021)$ & $(0.27725)$ \\
\hline & {$[-2.25472]$} & {$[-1.59569]$} & {$[-1.53231]$} & [2.12132] & {$[-0.06682]$} & {$[-1.12613]$} & [1.53624] \\
\hline \multirow[t]{3}{*}{$\mathrm{D}(\ln \mathrm{I}(-2))$} & -0.44157 & -0.57058 & -0.53027 & 1.798643 & 0.223566 & -0.29514 & 0.413684 \\
\hline & $(0.34942)$ & $(0.33878)$ & $(0.53905)$ & (1.15027) & $(0.51445)$ & $(0.40078)$ & $(0.31729)$ \\
\hline & {$[-1.26371]$} & {$[-1.68421]$} & {$[-0.98371]$} & [1.56367] & [0.43457] & {$[-0.73641]$} & [1.30378] \\
\hline \multirow[t]{3}{*}{$\mathrm{D}(\ln r \mathrm{~T}(-1))$} & -0.63882 & -0.63747 & -0.74539 & -0.80763 & 0.360226 & -0.32086 & 0.327553 \\
\hline & $(0.44299)$ & $(0.42949)$ & $(0.68339)$ & $(1.45827)$ & $(0.65220)$ & $(0.50810)$ & $(0.40225)$ \\
\hline & [-1.44209] & [-1.48424] & {$[-1.09072]$} & {$[-0.55383]$} & [0.55232] & {$[-0.63150]$} & [0.81430] \\
\hline \multirow{3}{*}{$\mathrm{D}(\ln \mathrm{TO}(-2))$} & 0.179458 & 0.408026 & -0.02088 & -1.08556 & 0.559933 & 0.514639 & -0.11688 \\
\hline & $(0.27789)$ & $(0.26943)$ & $(0.42870)$ & $(0.91480)$ & $(0.40914)$ & $(0.31874)$ & $(0.25234)$ \\
\hline & [0.64578] & [1.51442] & {$[-0.04871]$} & [-1.18667] & [1.36856] & [1.61462] & {$[-0.46319]$} \\
\hline \multirow[t]{3}{*}{ C } & -0.00099 & 0.000168 & 0.000746 & -0.00203 & 0.002040 & -0.00025 & -0.00068 \\
\hline & $(0.00158)$ & $(0.00153)$ & $(0.00243)$ & $(0.00519)$ & $(0.00232)$ & $(0.00181)$ & $(0.00143)$ \\
\hline & {$[-0.62862]$} & [0.10967] & [0.30654] & {$[-0.39053]$} & [0.87840] & {$[-0.13597]$} & {$[-0.47097]$} \\
\hline
\end{tabular}

Table 6. Estimating equation and results.

\begin{tabular}{ccccc}
\hline Variable & Coefficient & Std. Error & t-Statistic & Prob. \\
\hline$C(1)$ & -0.66591 & 0.25394 & -2.62231 & 0.0192 \\
$C(2)$ & -0.5273 & 0.632977 & -0.83304 & 0.4179 \\
$C(3)$ & -0.73404 & 0.637513 & -1.15141 & 0.2676 \\
$C(4)$ & 1.174578 & 0.816607 & 1.438364 & 0.1709 \\
$C(5)$ & 1.401951 & 0.582673 & 2.40607 & 0.0295 \\
$C(6)$ & -0.4227 & 0.387975 & -1.08949 & 0.2931 \\
$C(7)$ & -0.31256 & 0.216542 & -1.44342 & 0.1695 \\
$C(8)$ & -0.03231 & 0.065827 & -0.49076 & 0.6307 \\
$C(9)$ & 0.076143 & 0.083914 & 0.907396 & 0.3785 \\
$C(10)$ & -0.19687 & 0.313807 & -0.62735 & 0.5399 \\
$C(11)$ & -0.29801 & 0.274456 & -1.08583 & 0.2947 \\
$C(12)$ & -0.68843 & 0.305329 & -2.25472 & 0.0395 \\
$C(13)$ & -0.44157 & 0.349425 & -1.26371 & 0.2256 \\
$C(14)$ & -0.63882 & 0.442986 & -1.44209 & 0.1698 \\
$C(15)$ & 0.179458 & 0.277893 & 0.645781 & 0.5282 \\
$C(16)$ & -0.00099 & 0.001578 & -0.62862 & 0.5391 \\
\hline
\end{tabular}

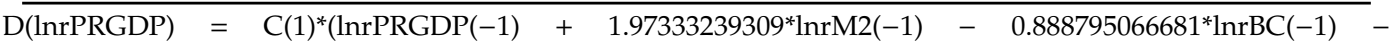
$0.0300235958207^{*} \ln S(-1)-1.4340302108^{*} \ln \mathrm{Cr}(-1)-0.751605839079^{*} \ln \mathrm{I}(-1)+0.22955429851^{*} \ln \mathrm{l}(-\mathrm{O}(-1)$ $-0.2116978611)+\mathrm{C}(2)^{*} \mathrm{D}(\ln r \mathrm{PRGDP}(-1))+\mathrm{C}(3)^{*} \mathrm{D}(\ln r \mathrm{PRGDP}(-2))+\mathrm{C}(4)^{*} \mathrm{D}(\ln r \mathrm{M} 2(-1))+\mathrm{C}(5)^{*} \mathrm{D}(\ln \mathrm{nM} 2(-2))$

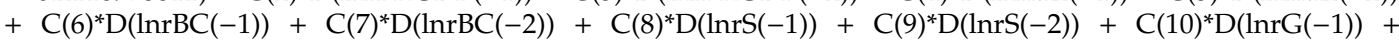
$\mathrm{C}(11)^{*} \mathrm{D}(\operatorname{lnr} \mathrm{G}(-2))+\mathrm{C}(12)^{*} \mathrm{D}(\ln r \mathrm{I}(-1))+\mathrm{C}(13)^{*} \mathrm{D}(\ln \mathrm{I}(-2))+\mathrm{C}(14)^{*} \mathrm{D}(\ln r \mathrm{TO}(-1))+\mathrm{C}(15)^{*} \mathrm{D}(\ln r \mathrm{TO}(-2))+\mathrm{C}(16)$.

The results indicate that, in the long run, bank credit has a significantly positive impact on the growth of the private sector. A $1 \%$ increase in bank credit to the private sector increases private sector GDP by $0.88 \%$. As the bank claims that the private sector has a positive and significant relationship, it is interpreted that banks will have an important role in the growth of the private sector of the country. 
This result goes along with all of the previous studies using bank claim to the private sector as a proxy for financial development, except for Ibrahim (2013). Moreover, share market capitalization has no significant relationship with that of the private sector's gross domestic product. Previous studies of Ibrahim (2013) and Samargandi et al. (2014) also had similar results. The only unexpected result is that broad money negatively relates to private sector growth. Previous studies have also shown different results for the relationship between financial development and economic growth, depending on the choice of the indicator.

Table 7. Residual diagnostics.

\begin{tabular}{ccc}
\hline Test & Test Statistic & $p$-Value \\
\hline Breusch-Godfrey Serial Correlation LM Test: & 0.330442 & 0.8477 \\
Heteroskedasticity Test: Breusch-Pagan-Godfrey & 20.74634 & 0.4745 \\
Jarque-Bera & 0.537758 & 0.764236 \\
\hline
\end{tabular}

Table 8. Wald's test for short-run causality.

\begin{tabular}{ccc}
\hline Hypothesis & Chi-Square Value & Probability \\
\hline $\mathbf{c}(\mathbf{4})=\mathbf{c}(\mathbf{5})=\mathbf{0}$ & 5.817595 & 0.0545 \\
$\mathbf{c ( 6 )}=\mathbf{c}(\mathbf{7})=\mathbf{0}$ & 2.979553 & 0.2254 \\
$\mathbf{c ( 8 )}=\mathbf{c}(\mathbf{9})=\mathbf{0}$ & 2.887682 & 0.236 \\
$\mathbf{c ( 1 0 )}=\mathbf{c}(\mathbf{1 1})=\mathbf{0}$ & 1.196024 & 0.5499 \\
$\mathbf{c ( 1 2 )}=\mathbf{c}(\mathbf{1 3})=\mathbf{0}$ & 5.107715 & 0.0778 \\
$\mathbf{c ( 1 4 )}=\mathbf{c}(\mathbf{1 5})=\mathbf{0}$ & 2.744756 & 0.2535 \\
\hline
\end{tabular}

The study reports a negative relationship between the ratio of M2/GDP and private sector growth. This contradicts the study of Marashdeh and Al-Malkawi (2014), which reported a positive relationship between the two for Saudi Arabia. However, the negative relationship between monetization ratio (M2/GDP) may be because of under-development of the financial sector below the threshold point, weak regulatory environment in the financial sector, business cycle obscuring long-run association, positive association between increased exchange of liquid into less-liquid investment and economic growth, lack of proper investment environment essential to nurture substantial private investment, lack of profitable investment opportunities, and high dependence on oil sector (Al-Yousif 2002; Gillman and Harris 2004; Mohamed 2008; Al-Malkawi et al. 2012; Mahran 2012; Grassa and Gazdar 2014; Barajas et al. 2013).

The control variables, namely, government expenditure, investment, and trade openness, also have a positive and significant impact on the private sector's gross domestic product, as expected. A 1\% increase in government expenditure increases the private sector GDP by $1.43 \%$. A $1 \%$ increase in gross domestic capital formation increases the private sector GDP by $0.75 \%$. A $1 \%$ increase in trade openness increases the private sector GDP by $0.22 \%$. These results are similar to the results of earlier studies. The results indicate that all three variables, namely, government expenditure, investment, and trade openness, facilitate the growth of the private sector. However, such a relationship is missing in the short run.

In a predominantly oil exporting economy like Saudi Arabia, the relationship between financial development and economic growth is not as important as in any other country (Grassa and Gazdar 2014). This predominance of oil provides the private sector with small a scope to contribute to economic growth. This in a sense leads to inefficient allocation of resources to less productive sectors (Mahran 2012). The non-competitiveness of non-oil sector results in lower revenues (Barajas et al. 2013). In a non-oil exporting country, the financial sector plays a greater role in resource allocation to firms, and subsequently revenue generation. Meanwhile, in an oil exporting country, the major economic activity is concentrated in generating revenue from processing oil, which happens to be a highly demanded commodity (Samargandi et al. 2014). Studies have cautioned against the usage of 
financial indicators to study economic growth, as expansionary monetary policy will not be effective in the absence of productivity (Gillman and Harris 2004).

High dependence of the oil sector and underdeveloped financial system can be the reason for a negative relationship between economic growth and financial development. Hence, this study recommends for greater financial deepening in banks as well as stock markets by improving access to financial institutions and increased competition in the financial sector. In addition, in line with Barajas et al. (2013), doing away with dominant fiscal policy and restrictive monetary policy might be a way to divert funds to the private sector. As a solution, this study recommends, in line with Samargandi et al. (2014), to increase the degree of diversification for the financial sector to contribute more to economic growth.

The share market of Saudi Arabia is considered not so efficient compared with its peers in mid-2015. The performance of Tadawul All Share Index (TASI) was poorer than the equity markets among global and regional peers (Jadwa Investment 2016). In 2017, the Saudi stock market started its journey of success with the launch of Nomu, which is a regulatory set-up for the equity market by the Capital Market Authority (CMA). It permitted space for investment by Saudi and Gulf companies, and also for qualified institutional investors (QFIs). Moreover, the Saudi stock market was upgraded to an emerging market from its standalone market position in the year 2018, and included in Morgan Stanley Index MSCI's Emerging Market Index in two phases in the year 2019. Therefore, the factors discussed above contributed to the rise of TASI by 15 percent since the start of 2019 (Jadwa Investment 2019).

Concurrent to the budget of 2018, the government disclosed that a total of SR133 billion would be spent by the Public Investment Fund (PIF) and the National Development Fund (NDF). Separately, prior to the budget, SR72 billion worth of activities was announced to encourage growth in the private sector. Furthermore, the foreign investors have pumped their investments to a large extent into the Saudi share market, and these investments shall help the kingdom in the development of the private sector. The government has a plan under Vision 2030 to increase its investment in the private sector by opening up new investment opportunities. Moreover, the government currently opened investment opportunities in the private sector, such as education and health, which were previously served by the public sector.

The current research suggests the government to increase the private sector's contribution in different sectors, such as energy, housing and finance, municipal services, and so on, by encouraging investments by nationals and foreign investors. The investments can be brought in through the capital market. Further, as Saudi Aramco has also gone for an Initial Purchase Offer (IPO) in 2019, the government can further plan for an IPO in its public sector companies. Aramco is the world's largest nationalized oil producer. Even it can encourage the large private sector companies to go for an IPO. Further, it can encourage the foreign direct investments in the proposed private sectors. The stock market should be more regulated and more private companies should be given provision to list in TASI, so that it can become a developed market. These improvements can lead to further growth in the private sector.

\section{Conclusions}

Though there have been many attempts to study the relationship between financial variables and economic growth, this study innovates by emphasizing the private sector. To the best knowledge of the researcher, there is no other study in the context of the private sector and financial sector. The closest study is of Samargandi et al. (2014), which studied non-oil sector and financial development and found a positive relationship between the two. The non-oil sector constitutes both the private sector and the government non-oil sector. Hence, the significance of this study stems from the fact that this study attempts to study the impact of financial factors on the private sector GDP of Saudi Arabia. Moreover, expanding this study by including other financial variables like M3 and the insurance sector can be the scope of further study. 
Private sector not only boosts the volume of GDP, but also promotes economic diversification, generates employment, and enhances productivity and competitiveness in the economy. Besides government expenditure, investment, and trade openness, financial markets are important enablers of the private sector. The private sector always has a need to expand its financing options and look for new options. The results indicate that bank credit to the private sector, government expenditure, investment, and trade openness significantly relate with private sector gross domestic product, in the long run.

The ongoing structural transformation program going on in the country to move away from oil provides both an opportunity and a challenge to the financial sector. The private sector has to come forward to attain diversification of the economy. Towards this, the financial sector has to play a bigger role to strengthen the private sector. The link between financial development and private sector economic growth established by the current study is of mixed nature. Out of the three financial variables studied, only bank credit to the private sector has a positive and significant relationship with the private sector growth. The ratio of broad money to GDP has a negative relationship and share market capitalization did not have a significant relationship with private sector growth. This indicates that the financial sector is still in the transition stage.

On the basis of the results, the study recommends further strengthening of financial sector services. The financial sector development can be instrumental in channeling oil receipts to productive ventures. In addition, the current trends in government expenditure, investment, and trade openness should continue to enable the private sector to contribute significantly to the economic growth of the country. This is important in view of the renewed emphasis on the private sector as the country is attempting to diversify itself and move away from the predominant oil sector. Increasing the resilience of the share market is a key recommendation of this study as an efficient capital market facilitates both investors and borrowers, leading to diversified and strong economic growth.

Funding: This research received no external funding.

Conflicts of Interest: The author declares no conflict of interest.

\section{References}

Abu-Bader, Suleiman, and Aamer S. Abu-Qarn. 2008. Financial development and economic growth: The Egyptian experience. Journal of Policy Modeling 30: 887-98. [CrossRef]

Agoraki, Maria-Eleni K., Dimitris A. Georgoutsos, and Georgios P. Kouretas. 2019. Capital markets integration and cointegration: Testing for the correct specification of stock market indices. Journal of Risk and Financial Management 12: 186. [CrossRef]

Allen, Franklin, and Douglas Gale. 2004. Financial intermediaries and markets. Econometrica 72: $1023-61$. [CrossRef]

Al-Malkawi, Husam-Aldin N., Hazem A. Marashdeh, and Naziruddin Abdullah. 2012. Financial development and economic growth in the UAE, empirical assessment using ARDL approach to co integration. International Journal Economic Finance 4: 105-5. [CrossRef]

Al-Tamimi, Hussein A. Hassan, Mouawiya Al-Awad, and Husni A. Charif. 2001. Finance and growth, evidence some Arab countries. Journal of Transnational Management Development 7: 3-18. [CrossRef]

Al-Yousif, Yousif Khalifa. 2002. Financial Development and Economic Growth another look at the Evidence from Developing Countries. Review of Financial Economics 11: 1-20.

Ayad, Hicham, and Mostéfa Belmokaddem. 2017. Financial development, trade openness and economic growth in MENA countries, TYDL panel causality approach. Theoretical and Applied Economics XXIV: 209-22.

Aziakpono, Meshach. 2013. Financial integration and economic growth: Theory and a survey of evidence. Journal for Studies in Economics and Econometrics 37: 61-86.

Barajas, Adolfo, Ralph Chami, and Seyed Reza Yousefi. 2013. The Finance-Growth Nexus Re-Examined, Do All Countries Benefit Equally? IMF Working Paper 13/130. Washington: International Monetary Fund.

Beck, Thorsten. 2011. Finance and Oil: Is There a Resource Curse in Financial Development. European banking Centre Discussion Paper No. 2011-007. Tilburg: Tilburg University. 
Belloumi, Mounir, and Atef Alshehry. 2018. The impacts of domestic and foreign direct investments on economic growth in Saudi Arabia. Economies 6: 18. [CrossRef]

Christopoulos, Dimitris, and Mike Tsionas. 2004. Financial development and economic growth, Evidence from panel unit root and cointegration tests. Journal of Development Economics 73: 55-74. [CrossRef]

Darrat, Alif F. 1999. Are financial deepening and economic growth causally related? Another look. International Economic Journal 13: 19-35. [CrossRef]

Darrat, Alif. F., Salah S. Abosedra, and Hassan Y. Aly. 2005. Assessing the role of financial deepening in business cycles, The experience of United Arab Emirates. Applied Financial Economics 15: 447-53. [CrossRef]

De Gregorio, José, and Se-Jik Kim. 2000. Credit markets with differences in abilities, education, distribution and growth. International Economic Review 41: 579-607. [CrossRef]

Demirgüç-Kunt, Asli, and Vojislav Maksimovic. 1996. Stock market development and financing choices of firms. The World Bank Economic Review 10: 341-69. [CrossRef]

Dibooglu, Selahattin. 1993. Multiple cointegration and structural models: Applications to exchange rate determination. Retrospective Theses and Dissertations, 10420. Available online: https://lib.dr.iastate.edu/rtd/ 10420 (accessed on 10 January 2020).

Duasa, Jarita. 2014. Financial development and economic Growth, The experiences of selected OIC countries. International Journal of Economics and Management 8: 215-28.

Eatwell, John. 1996. International financial liberalization: The impact on world development. In CEPA Working Paper Series 1. New York: New School for Social Research.

Gillman, Max, and Mark Harris. 2004. Inflation, Financial Development and Growth in Transition Countries. Working Paper No. 23/04. Department of Econometrics and Business Statistics, Monash University.

Grassa, Rihab, and Kaouthar Gazdar. 2014. Financial development and economic growth in GCC countries. International Journal of Social Economics 41: 493-514. [CrossRef]

Greenwood, Jeremy, and Boyan Jovanovic. 1990. Financial development, growth, and the distribution of income. The Journal of Political Economy 98: 1076-107. [CrossRef]

Greenwood, Jeremy, and Bruce D. Smith. 1997. Financial markets in development, and the development of financial markets. Journal of Economic Dynamic and Control 21: 145-81. [CrossRef]

Greenwood, Jeremy, Juan M. Sanchez, and Cheng Wang. 2013. Quantifying the impact of financial development on economic development. Review of Economic Dynamics 16: 194-215. [CrossRef]

Hamdi, Helmi. 2015. Financial Reform and Economic Development. Economies 3: 235-36. [CrossRef]

Hamdi, Helmi, Rashid Sbia, and Bedri Kamil Onur Tas. 2014. Financial deepening and economic growth in Gulf Cooperation Council Countries. International Economic Journal 28: 459-73. [CrossRef]

Hasanov, Fakhri J., Lester C. Hunt, and Ceyhun I. Mikayilov. 2016. Modeling and forecasting electricity demand in azerbaijan using cointegration techniques. Energies 9: 1045. [CrossRef]

Hassan, Mohammad Kabir, Benito Sanchez, and Jung-Suk Yu. 2011. Financial development and economic growth in the organization of Islamic Conference Countries. JKAU Islamic Economics 24: 145-72.

Hathroubi, Salem. 2019. Inclusive finance, growth and socio-economic development in Saudi Arabia, A Threshold Cointegration Approach. Journal of Economic Development 44: 77-111. [CrossRef]

Henry, Peter Blair. 2006. Capital account liberalisation: Theory, evidence, and speculation. In NBER Working Paper 12698. Cambridge: NBER.

Huang, Xin. 2019. Persistence of bank credit default swap spreads. Risks 7: 90. [CrossRef]

Ibrahim, Mohamed Abbas. 2013. Financial development and economic growth in Saudi Arabian Economy. Applied Econometrics and International Development 13: 133-44.

Jadwa Investment. 2016. The Saudi Stock Exchange (Tadawul) in 2016. Available online: http://www.jadwa.com/ en/researchsection/research/capital-market (accessed on 1 April 2020).

Jadwa Investment. 2019. Saudi Stock Market Update. Available online: http://www.jadwa.com/en/researchsection/ research/capital-market (accessed on 1 April 2020).

Jehle, Geoffrey A., and Philip J. Reny. 2001. Advanced Microeconomic Theory, 2nd ed. New York: Addison-Wesley.

Kose, M. Ayhan, Eswar Prasad, Kenneth Rogoff, and And Shang-Jin Wei. 2006. Financial globalization: A reappraisal. In NBER Working Paper 12484. Cambridge: NBER.

King, Robert G., and Ross Levine. 1993. Finance, entrepreneurship and growth: Theory and Evidence. Journal of Monetary Economics 32: 1-30. [CrossRef] 
Kouki, Imen. 2013. Financial development and economic growth in the North Africa Region. African Development Reviewer 25: 551-62. [CrossRef]

Law, Siong Hook, and Nirvikar Singh. 2014. Does too much finance harm economic growth? Journal of Banking and Finance 41: 36-44. [CrossRef]

Law, Siong Hook, and Maryam Moradbeigi. 2017. Financial development and oil resource abundance-growth relations, evidence from panel data. Environmental Science and Pollution Research 24: 22458-75. [CrossRef] [PubMed]

Levine, Ross. 2005. Finance and growth: Theory and evidence. In Handbook of Economic Growth. Edited by Philippe Aghion and Steven Durlauf. Elsevier Science.

Levine, Ross, and Sara Zervos. 1998. Stock markets, banks, and growth. American Economic Review 88: 537-58.

Loayza, Norman, and Romain Ranciere. 2006. Financial development, financial fragility, and growth. Journal of Money Credit and Banking 38: 1051-76. [CrossRef]

Lohmann, Susanne. 1992. Optimal commitment in monetary policy: Credibility versus flexibility. American Economic Review 82: 273-86.

Lucas, Robert E. 1988. On the mechanics of economic development. Journal of Monetary Economics 22: 3-42. [CrossRef]

Mahran, Hatim Ameer. 2012. Financial intermediation and economic growth in Saudi Arabia, An Empirical Analysis, 1968-2010. Modern Economics 3: 626-40. [CrossRef]

Marashdeh, Hazem A., and Husam-Aldin N. Al-Malkawi. 2014. Financial deepening and economic growth in Saudi Arabia. Journal of Emerging Market Finance 13: 139-54. [CrossRef]

Masih, Mansur, Ali Al-Elg, and Haider Madani. 2009. Causality between financial development and economic growth, an application of vector error correction and variance decomposition methods to Saudi Arabia. Applied Economics 41: 1691-99. [CrossRef]

McKinnon, Ronald I. 1973. Money and Capital in Economic Development. Washington: Brookings Institution.

Mohamed, Sufian Eltayeb. 2008. Finance-growth nexus in Sudan: Empirical assessment based on an application of the autoregressive distributed lag $(A R D L)$ model. Working Paper Series 0803; Kuwait: Arab Planning Institute.

Muhammad, Naeem, Abu Reza Mohammad Islam, and Hazem A. Marashdeh. 2016. Financial development and economic growth, an empirical evidence from the GCC countries using static and dynamic panel data. Journal of Economics and Finance 40: 773-91. [CrossRef]

Patrick, Hugh T. 1966. Financial development and economic growth in underdeveloped countries. Economic Development and Cultural Change 14: 147-89. [CrossRef]

Rajan, Raghuram G., and Luigi Zingales. 1998. Financial dependence and growth. American Economic Review 88: 559-86.

Rehman, Mohammed Ziaur. 2018. Banking Sector Development, Stock market development and economic growth, Evidence from Saudi Arabia. Academy of Accounting Financial Studies Journal 22: 1-15.

Rioja, Felix, and Neven Valev. 2004. Does one size fit all? A reexamination of the finance and growth relationship. Journal of Development Economics 74: 429-47. [CrossRef]

Robinson, Joan. 1952. The generalization of the general theory. In The Rate of Interest and Other Essays. London: Macmillan.

Samargandi, Nahla, Jan Fidrmucand, and Sugata Ghosh. 2014. Financial development and economic growth in an oil-rich economy, The case of Saudi Arabia. Economic Modelling 43: 267-78. [CrossRef]

SAMA. 2019. Forty-Sixth Annual Report, Saudi Arabian Monetary Authority, Riyadh. Available online: http://www.sama.gov.sa/en-US/EconomicReports/Pages/YearlyStatistics.aspx (accessed on 10 January 2020).

Schumpeter, Joseph A. 1911. The Theory of Economic Development. Cambridge: Harvard University Press.

Shaw, Edward S. 1973. Financial Deepening in Economic Development. New York: Oxford University Press.

Stern, Nicholas. 1989. The economics of development: A survey. Economic Journal 99: 597-785. [CrossRef]

Vision 2030. Plan Document. Available online: https://english.alarabiya.net/en/perspective/features/2016/04/26/ Full-text-of-Saudi-Arabia-s-Vision-2030.html (accessed on 10 January 2020).

Wickens, Michael R. 1996. Interpreting cointegrating vectors and common stochastic trend. Journal of Econometrics 74: 255-71. [CrossRef]

(C) 2020 by the author. Licensee MDPI, Basel, Switzerland. This article is an open access article distributed under the terms and conditions of the Creative Commons Attribution (CC BY) license (http://creativecommons.org/licenses/by/4.0/). 